\title{
Different Strokes of Creativity: Personality and Entrepreneurial Intent Among Workers of Telecom Industry in Nigeria
}

\author{
Fasanmi, Samuel Sunday \\ Department of Psychology, Olabisi Onabanjo University, \\ Ago-Iwoye. Ogun State. Nigeria \\ Osungboye, Biola Muhibat \\ Department of Public Administration, Olabisi Onabanjo University, \\ Ago-Iwoye. Ogun State. Nigeria
}

Doi:10.19044/esj.2018.v14n20p283 URL:http://dx.doi.org/10.19044/esj.2018.v14n20p283

\begin{abstract}
The study examined personality traits as predictors of entrepreneurial intention among managers of telecom industries in Nigeria. Opinions of two hundred and five (205) respondents were randomly sampled across various offices of Globacom Plc in Lagos State, Nigeria. A battery of standardized tests was administered on them using a cross-sectional survey research design. One hypothesis was tested in the study. Results revealed that extraversion $(\beta=0.147, \mathrm{t}=2.582 ; \mathrm{P}<.05)$, neuroticism $(\beta=-.271, \mathrm{t}=4.358$; $\mathrm{P}<.05)$, openness to experience $(\beta=.224, \mathrm{t}=3.456 ; \mathrm{P}<.05)$ are significantly independently predicted entrepreneurial intention among managers of telecom industries in Nigeria. It was also found out that extraversion, agreeableness, conscientiousness, neuroticism, and openness to experience significantly and jointly predicted entrepreneurial intention among managers of telecom industries in Nigeria $\{\mathrm{F}(6,204)=24.895 ; \mathrm{P}<.05\}, \mathrm{R}^{2}=.413$. Results were discussed in line with the literature. It was recommended that since this study has established a strong relationship between personality traits and entrepreneurial intentions, telecom industries should as a matter of urgency include personality identification in their training regimen, this will go a long way in bringing fulfillment to managers, and consequently better the lots of their companies.
\end{abstract}

Keywords: Entrepreneurial Intent, Personality, Telecommunication 


\section{INTRODUCTION}

There is clear pall of uncertainty that is cast in Nigeria telecommunication industry. No doubt, only oil and gas has the higher income generation than this sector as it boasts of a large chunk of income for Nigeria. However, the Nigerian Communications Commission (NCC) has disclosed that active telecommunication subscribers reduced from 152,467,198 in March, 2017 to 149,249,510 in the month of April. It said that the active telecommunications service customers declined by 3,217,688 in April, as against 152,467,198 in March, 2017 (Premium Times, June 12, 2017). Beside the decline of GSM mobile subscribers, other major challenges facing telecommunication industry include: fierce price competition among telecom operators on their voice and internet data, Dominance of only major companies with enough financial stamina, difficulties accessing foreign currency (FX) to finance their dollar/FX debt, decline in their equity instruments impeding their ability to absorb losses. Thus, survival, long-term growth and sustainability, are now functions of innovative business practices that are anchored on investing their assets in more creative services that focus primarily on meeting consumer needs and establish a regulated minimum market price.

The concept of corporate entrepreneurship can be defined as the development of new ideas and opportunities within large or established businesses, directly leading to the improvement of organizational profitability and an enhancement of competitive position or the strategic renewal of an existing business (Zahra, 1991). Innovativeness drives corporate entrepreneurship. Fortunately, the twain concepts are responsible for driving calculated and beneficial risk-taking. Thus corporate entrepreneurship is conceived of as the efforts to extend an organisation's competitive advantage through internally generated innovations that significantly alter the balance of competition within an industry or create entirely new industries. This can only be achieved when candidates are the right fit to the job, the organization, and the management increases the probability of employee affective commitment, reduces turnover intention after being hired (Fasanmi, 2018). Organisation does better in coasting in that path when in their quest to achieve such noble success, right personality a characteristic of an individual is put into consideration.

Personality can be defined as the pattern of thoughts, feelings, social adjustment and behaviours consistently exhibited over time that strongly influence one's expectations, self-perception, values and attitude (Winnies and Gittinge, 1973). Personality trait is becoming popular as an explanation of entrepreneurial behaviors and intentions. Contemporary theorist identifies five fundamental personality dimensions which are extroversion, 
neuroticism, agreeableness, conscientiousness and openness to experience. Traits predicting behaviour include risk taking, achievement motivation and locus of control. Ismail, Khalid, Othman, Jusoff, Abdul, Mohammed, \& Shekh, (2009) found out that only extraversion, and openness to experience had significant correlation with entrepreneurial intention while other personality factors such as conscientiousness, agreeableness, neuroticism did not show significant relationship.

This research intends to consider unique population-managers of telecom industries. This novel adventure will not only better the telecom industries, but also an advancement in research considering the fact that there are little research efforts in this area of study.

\section{LITERATURE REVIEW}

Social network theory proposes that social behavior and communication are affected by the patterns of ties among people. Studies of social networks have surveyed the social interactions of specific individuals by lists of persons contacted and by measuring the frequency of their interactions (Hampton \& Wellman, 1999). Social network theory suggests that the more people are socially connected, the more intensely they are likely to communicate using various media available to them. Social network theory is applicable to describe human relationships across two media, like communication face-to-face or through electronic means. Like previous advances in communication technology, the Internet continues the process of connecting people participating in social networks and geographically dispersed people and organizations bound by shared interests (Haythornthwaite \& Wellman, 1998; Wellman, Haase, Witte, \& Hampton, 2001). Social network theory suggests that Internet social communication supplements and is an extension of traditional social behaviors. In line with the social network perspective, it has been found that the more individuals in organizations are connected, communicate face-to-face, and the more intimate their relationships, the more frequently and intimately they use email and a variety of media to communicate (Haythornthwaite \& Wellman, 1998). In other words, the Internet supplements traditional social behavior, without necessarily increasing or decreasing it (Wellman et al., 2001). This is true not only for adults but for teenagers as well (Lenhart, Rainie, \& Lewis, 2001).

These perspectives also fit well with network social influence theory that describes the effects of various types of social organizations on attitudes and behaviors (Rice, 1993). Research in this area has found that specific interactions in social networks have more influence on specific attitudes and behaviors than more general social factors like group membership. Therefore, we would expect interaction within traditional social networks to 
carry over to Internet social communication. In line with social network theory, we expected a positive association between traditional social behavior and Internet social communication. The more a person interacts traditionally and the more intimate his or her relationships, the more that person would use the Internet to maintain communication with others and the more intimate would be their online communication.

Cognitive dissonance theory posits that when a person is faced with inconsistencies among attitudes or behaviours, he or she tries to resolve the dissonance by changing an attitude or modifying behaviour (Festinger, 1957). People always encounter conflict between attitudes and behaviours. People are motivated to reduce the negative feelings caused by dissonance by fitting dissonant elements together. A cognitive element can be something a person believes, a behaviour engaged, or observations about surroundings. For instance, a person believes smoking is bad but still smokes. Such psychological inconsistency creates a feeling of discomfort. The feeling of dissonance depends on both the importance and number of dissonant elements. Dissonance theory helps to explain why evaluations of a product tend to increase after it has been purchased.

The traits theorists offer a micro-perspective of what can be considered as enduring factors, which lead to entrepreneurship, such as the persona of the entrepreneur, cultural affiliation and personal motivation. This perspective focuses on the psychological, social, cultural, and ethnic characteristics of individuals involved in entrepreneurship (Thornton, 1999). These approaches emphasize the entrepreneur's dispositional profile characterized by the traits mentioned above among other attributes. But Chell (2000) suggests that it is not clear whether some of the studied attributes precede entrepreneurial behaviour or whether entrepreneurs acquire them in the process. Furthermore, entrepreneurs may possess some, but not necessarily all of the traits highlighted in the literature, bringing us to the conclusion that not one stereotypical personality model fits.

The Big-Five factor model is the dominant model for representing the human trait structure today ((Roccas Sagiv, Schwartz, \& Knafo, 2002). Traits are "dimensions of individual differences in tendencies to show consistent patterns of thoughts, feelings and actions" (McCrae \& Costa, 1990, p. 29). This means that traits are enduring dispositions. Values on the contrary, are enduring goals. These traits describe what people are like, rather than the intentions that fuel the behavior (Roccas, Sagiv, Schwartz, \& Knafo, 2002).

The big-five factor model claims to represent comprehensively the basic factors that organize human traits (Saucier \& Goldberg, 1998). There is discussion about the existence of different or more factors, yet only a few have been proposed (Tellegen, 1993). This disagreement may be caused by 
the multi-faceted nature of the factors. Different components and nuances have been suggested as additions or changes to the current five factors by several scientists (Hogan \& Ones, 1997) (McCrea \& Costa, 1997) (Sackett \& Wanek, 1996) (Saucier \& Ostendorf, 1999).

The Big Five and entrepreneurial success Meta-analytical research review tends to be reliable as it focuses on several different sources of data (Babbie, 2007). Therefore this is a good basis for this research. The results show each relationship between entrepreneurial performance and the five personality factors. These dimensions are related to entrepreneurial intentions. The succinct relationship that exit among the variables are discussed below.

Extraversion can be described as being sociable, assertive and directive. Kaczmarek \& Kaczmarek-Kurczak, (2016) opined that extraverts tend to score high on risk-taking, energy-level, activity-level, dominance and optimism. It is thus posited that entrepreneur that scores high on extraversion performs better than an entrepreneur that scores low on extraversion. Also, Cantner, Silbereisen, \& Wilfling, (2011) were of the opinion that entrepreneurs that are extraverted are less likely to fail, as they tend to strive for higher sales profits. This assertion according to them is not unconnected to the fact that higher extraversion raises the sensitivity for rewards. Openness to experience has been found to be related to entrepreneurial intention. Entrepreneurs who are more open to new experience are more likely to be successful because of these three dimensions (Slavec, 2014). Conscientiousness shows the strongest and most consistent association with entrepreneurial intention (Zhao, Seibert, \& Lumpkin, Brandstätter, 2011). Also a positive relationship was established between conscientiousness and both job performance and entrepreneurial intention (Ciavarella, Buchholtz, Riordan, Gatewood, \& Stokes, 2004; Hurtz \& Donovan, 2001; and Leutner, Ahmetoglu, Akhtar, \& Chamorro-Premuzic, 2014).

\section{METHODOLOGY}

This research employed a cross-sectional survey. The population of this study consisted of some of the staff of Glo in Lagos State. There were 1670 staff (both contract and permanent staff) at Glo Office in Lagos. The research covered all cadres of staff in the company. The researcher used sample size calculator to estimate the sample size based on the population of the staff of Glo in Lagos. An estimated two hundred participants comprising of both male and female that cut across various cadre of staff; and job status was used for the study. showed that (112) 54.6\% of the participants are male while (93) $45.4 \%$ are female. of the participants $108(52.7 \%$ ) are $30-39$ 
years old, $62(30.2 \%)$ are $40-50$ years old, while $7(3.4 \%)$ are below 20 years, $14(6.8 \%) 20-29$ years old and $14(6.8 \%)$ are above 50 years.

The Nigerian telecommunication sector is the largest segment of the Information and Communication sector. Nigeria has one of the largest telecom markets in Africa. The Nigerian Telecommunication sector has evolved over the years to an oligopolistic market structure (a small number of firms have the majority of market share). The sector includes a strong multinational presence. The leading players are MTN, a South African based multinational company with a market share of $37.21 \%$, Airtel (an Indian based multinational telecommunication), Glo (a Nigerian multinational company) and 9mobile (formerly Etisalat).

Multi-stage sampling technique was used in this research. The purposive sampling technique was used in selecting the Glo Lagos. This was not unconnected with high concentration of staff for ease of access. Stratified sampling technique in which various departments served as strata was used in distributing the questionnaire across various groups in the company. Accidental sampling technique was used during the administration of the questionnaire. This sampling technique gives room for all the participants who were available to be selected for the study.

The questionnaire consists of four sections. Section A measures the biodata information of the respondents. These include: age, job status and marital. Section B contained Big-Five Personality Inventory, section C consists Entrepreneurial intention questionnaire. The Entrepreneurial Intention Questionnaire (EIQ) was originally developed in Spain by Moriano (2005). The EIQ comprises four subscales: attitudes towards entrepreneurship, subjective norms, PBC, and entrepreneurial intention. All items in the questionnaire were measured on a 5-point Likert Scale (from 1 to 7). The Cronbach alpha reliability of the EIQ subscales in previous research ranged from .76 to .87 in Spanish sample of 281 students and from .77 to .87 in Polish sample of 154 students (Laguna, Moriano, Roznowski, \& Gómez, 2008). The EIQ measures PBC through entrepreneurial self-efficacy in line with other research on entrepreneurial intentions (Krueger, Jr, Reilly, and Carsrud, 2000; Kolvereid \& Isaksen, 2006; Moriano, 2005; van Gelderen, Brand, van Praag, Bodewes, Poutsma, \& van Gils, (2008). The five-item entrepreneurial self-efficacy scale has reliability coefficient of alpha .80. High scores indicate high entrepreneurial self-efficacy.

Big Five Personality questionnaire was designed by John \& Srivastava in 1999. The scale is a 44-item inventory that measures an individual on the Big Five Factors (dimensions) of personality (Goldberg, 1993). Each of the factors is then further divided into personality facets. Entrepreneurial intention was measured using a four-item scale (alpha .86) in which each item assesses the perceived likelihood of an individual to choose 
an entrepreneurial career. Higher scores reflect stronger entrepreneurial intentions.

Consent of the participant was sought by sending letter to the organization explaining the purpose of the research. The researcher distributed copies of questionnaire to the respondents on the spot. The questionnaires were administered to the respondents during their work free periods.

Hypotheses were tested using Pearson Product Moment Correlation and multiple regression analysis.

\section{RESULTS}

Results of all the analysis including hypotheses testing were presented in this section. The means, standard deviations and zero-order correlations of variables measured with interval scales and the results of the hypotheses tested are presented in this chapter. Table 1 showed a correlation matrix of the variables measured in the continuous format in this study. Inter-Correlations between Predictor Variables and the Criterion Variables

Table 1 showed the correlation among the sampled variables. The table revealed that rank, educational qualification, extraversion and openness to experience have significant negative relationship with entrepreneurial intention among managers of telecommunication industries in Nigeria. The table also showed that neuroticism and self-efficacy are positively related to entrepreneurial intention among managers of telecommunication industries in Nigeria. The implication of these findings is that positive correlation portends that the higher the entrepreneurial intention, the higher the score on that particular variable and vice versa. Negative correlation implies that the lower the level of entrepreneurial intention, the higher the score of the participant on the other variable. Tables 1 also revealed that sex, age, and conscientiousness have no significant relationship with entrepreneurial intention among managers of telecommunication industries in Nigeria. However, variables that are ordinal in nature would be judged by their coding status. The table also provides an avalanche of results showing relationship among all the variables. 
Table 1: Correlation Matrix of some Variables

\begin{tabular}{|c|c|c|c|c|c|c|c|c|c|c|c|c|c|}
\hline & Variables & Mean & SD & 1 & 2 & 3 & 4 & 5 & 6 & 7 & 8 & 9 & 10 \\
\hline 1. & Sex & 1.45 & .50 & - & & & & & & & & & \\
\hline 2. & Age & 3.30 & .83 & -.10 & - & & & & & & & & \\
\hline 3. & Rank & 2.07 & .51 & - & $.59 * *$ & - & & & & & & & \\
\hline 4. & Education & 2.23 & .56 & $.28 * *$ & $.35 * *$ & $.41 * *$ & - & & & & & & \\
\hline 5. & $\begin{array}{l}\text { Extraversio } \\
\mathrm{n}\end{array}$ & 22.05 & 1.70 & $.25 * *$ & $-.20 * *$ & $.24 * *$ & -.04 & - & & & & & \\
\hline 6. & $\begin{array}{l}\text { Agreeablen } \\
\text { ess }\end{array}$ & 26.15 & 2.18 & $.20 * *$ & $-.23 * *$ & $-.16^{*}$ & .06 & .06 & - & & & & \\
\hline 7. & CONT & 22.85 & 2.32 & .14 & .13 & .13 & -.16 & .05 & -.16 & - & & & \\
\hline 8. & Neuroticism & 21.43 & 2.03 & $.37 * *$ & $-.14 *$ & $.14^{*}$ & $-.17 *$ & 0 & -.12 & $.24 * *$ & - & & \\
\hline 9. & Openness & 29.67 & 2.65 & $-.14 *$ & $.21 * *$ & -.05 & $.15^{*}$ & $.22 * *$ & $.42 * *$ & $.34 * *$ & $.16^{*}$ & - & \\
\hline 10 & EI & 18.57 & 2.15 & -.06 & $.19 * *$ & -.06 & $.28 * *$ & .10 & - & $.24 * *$ & $.30 * *$ & $.40 * *$ & $.54 * *$ \\
\hline
\end{tabular}

- Significant at $.05 ; * *$ significant at .01 level

- CONT-Conscientiousness; SE-Self-efficacy; EI-Entrepreneurial intention; and Openness- Openness to experience. 
Hypothesis one stated that personality traits will significantly and independently predict entrepreneurial intention among managers of telecommunication industries in Nigeria.

Table 2: A Summary of Multiple Regression Analysis showing the influence of personality traits on entrepreneurial intention.

\begin{tabular}{|c|c|c|c|c|c|c|c|c|}
\hline Predictors & $\beta$ & $\mathrm{t}$ & $p$ & $\mathrm{R}$ & $\mathrm{R}^{2}$ & Adjusted $\mathrm{R}^{2}$ & $\mathrm{~F}$ & $p$ \\
\hline Extraversion & .147 & 2.582 & $<.05$ & & & & & \\
\hline Agreeableness & -.061 & -.848 & $>.05$ & & & & & \\
\hline Conscientiousness & .026 & .427 & $>.05$ & 13.84 & .430 & .413 & 24.895 & $<.05$ \\
\hline Neuroticism & -.271 & 4.358 & $<.05$ & & & & & \\
\hline Openness to experience & .224 & 3.456 & $<.05$ & & & & & \\
\hline
\end{tabular}

$N=205, \beta=$ Standardized regression weight computed at the end of each step, $R^{2}=$ Adjusted $R^{2}$.

Table 2 above showed that extraversion, agreeableness, conscientiousness, neuroticism, openness to experience and self-efficacy significantly and jointly predicted entrepreneurial intention among managers of telecom industries in Nigeria $\{\mathrm{F}(6,204)=24.895 ; \mathrm{P}<.05\}, \mathrm{R}^{2}=.413$.

The table also revealed that extraversion $(\beta=0.147, \mathrm{t}=2.582 ; \mathrm{P}<$ $.05)$, neuroticism $(\beta=-.271, \mathrm{t}=4.358 ; \mathrm{P}<.05)$, openness to experience $(\beta$ $=.224, \mathrm{t}=3.456 ; \mathrm{P}<.05)$, and self-efficacy $(\beta=.414, \mathrm{t}=6.352 ; \mathrm{P}<.05)$, significantly independently predicted entrepreneurial intention among managers of telecom industries in Nigeria. Meanwhile, agreeableness $(\beta$ $=0.061, \mathrm{t}=-.848 ; \mathrm{P}>.05)$, and conscientiousness $(\beta=.026, \mathrm{t}=.427 ; \mathrm{P}>.05)$, had no significant independent prediction on entrepreneurial intention among managers of telecommunication industries in Nigeria.

The table further revealed that $41.3 \%$ of the variance in entrepreneurial intention among managers of telecommunication industries in Nigeria was accounted for by the identified independent variables. Therefore, it can be said that hypothesis, one, two, and four were supported by the study's findings.

\section{DISCUSSION}

Hypothesis one revealed that personality traits would significantly predict entrepreneurial intention. The traits model assumes that personality traits are the basis for individual differences. Personality traits are defined as "characteristics of individuals that exert pervasive influence on a broad range of trait-relevant responses" (Ajzen, 2005, p2). The trait approach to entrepreneurship has been pursued by many researchers in an attempt to separate entrepreneurs from non-entrepreneurs and to identify a list of character traits specific to the entrepreneur. For instance McClelland (1971) 
and Rauch \& Frese (2000) suggest that need for achievement should be higher in people who start a business.

Similar result appears for locus of control (Rotter 1966), Innovativeness, competitive aggressiveness, and autonomy (Utsch et al. 1999), protestant work ethic beliefs (Bonnett \& Furnham 1991) and risk taking (Begley \& Boyd 1987), among others.

In the trait model, personality traits are seen as the determining factors of behavior that make a person perform in a relatively consistent way across various circumstances.(Bird, 1988) observed that traits are significantly associated with entrepreneurial motivation and intentions. The traits models rely on the assumption that entrepreneurs possess certain traits that distinguish them from others. These psychological traits, also called entrepreneurial characteristics, include achievement motivation, locus of control, risk-taking propensity, tolerance of ambiguity, self confidence, innovation, energy level, need for autonomy and independence, etc. There is no agreement however on the number of traits, specific to the entrepreneur, or their validity. In this thesis, only three of the most frequently confirmed personality traits, namely, need for achievement, risk-taking propensity and autonomy are adopted and reviewed. Rauch \& Frese (2007) used the same traits in their meta-analysis of the effect of personality on entrepreneurship

Kaczmarek \& Kaczmarek-Kurczak, (2016) opined that extraverts tend to score high on risk-taking, energy-level, activity-level, dominance and optimism. It is thus posited that entrepreneur that scores high on extraversion performs better than an entrepreneur that scores low on extraversion. Also, Cantner, Silbereisen, \& Wilfling, (2011) were of the opinion that entrepreneurs that are extraverted are less likely to fail, as they tend to strive for higher sales profits. This assertion according to them is not unconnected to the fact that higher extraversion raises the sensitivity for rewards. Openness to experience has been found to be related to entrepreneurial intention. Entrepreneurs who are more open to new experience are more likely to be successful because of these three dimensions (Slavec, 2014). Conscientiousness shows the strongest and most consistent association with entrepreneurial intention (Zhao, Seibert, \& Lumpkin, Brandstätter, 2011). Also a positive relationship was established between conscientiousness and both job performance and entrepreneurial intention (Ciavarella, Buchholtz, Riordan, Gatewood, \& Stokes, 2004; Hurtz \& Donovan, 2001; and Leutner, Ahmetoglu, Akhtar, \& Chamorro-Premuzic, 2014).

Personality trait is becoming popular as an explanation of entrepreneurial behaviors and intentions. Contemporary theorist identifies five fundamental personality dimensions which are extroversion, neuroticism, agreeableness, conscientiousness and openness to experience. 
Traits predicting behaviour include risk taking, achievement motivation and locus of control. Ismail et al. (2009) found out that only extraversion, and openness to experience had significant correlation with entrepreneurial intention while other personality factors such as conscientiousness, agreeableness, neuroticism did not show significant relationship.

\section{CONCLUSION}

Entrepreneurship plays an important role in a dynamic modern economy. In relation to each of the hypothesis, support was found for the effect of personality on entrepreneurial intentions. Self-efficacy and achievement motivation does seem to explain some variations in entrepreneurial intentions as discussed in the results.

Based on the findings of the study, the following are recommended:

1. People who have a high self-efficacy and who believe so much in themselves should be encouraged to start their own business so as to help reduce the rate of unemployment in the country.

2. The pragmatic teaching of entrepreneurship should be further encouraged in schools so as to increase the level of awareness among people.

3. Managers at all levels should be subjected to a battery of test to know their personality traits. This will not only help in placing them rightfully on the particular unit that suits their personality, but also promote their entrepreneurial abilities and intentions which will boost the profit matrix of their organizations.

4. Since this study has established a strong relationship between personality traits and entrepreneurial intentions, telecom industries should as a matter of urgency include personality identification in their training regimen, this will go a long way in bringing fulfillment to managers, and consequently better the lots of their companies.

The sample size was rather too small for the strength of the statistics adopted for the study. Fasanmi (2017), asserted that the larger the sample size of a population, the lower the variance, and consequently, the better the overall results. The small sample size would surely make results generalization very difficult. Thus, it is expedient for future researchers to take into cognizance the number of selected participants in ensuring better results.

The usage of one Telecom company might have sounded good; the uniformity in the culture of the industry could pose a major challenge to the generalization of the results of this study. Organisational culture varies across companies, policies also differ. 


\section{References:}

1. Ajzen, I., \& Fishbein, M. (2005). The influence of attitudes on behavior. In D. Albarracín, B. T. Johnson, \& M. P. Zanna (Eds.), The handbook of attitudes (pp. 173-221). Mahwah, NJ: Erlbaum.

2. Babbie, E. (2007). The practice of social research.Belmont CA: Thompson Higher Education.

3. Begley, T. M. \& Boyd, D. P. (1987). Psychological characteristics of associated with performance in entrepreneurial firms and small businesses. Journal of Business Venturing, 2: 79-83.

4. Bird, B., 1988. Implementing entrepreneurial ideas: the case for intention. Academy of Management Review 13, 442-453.

5. Bonnett, C., \& Furnham, A. (1991). Who wants to be an entrepreneur? A study of adolescents Entrepreneurial postures, interested in a young enterprise scheme. Journal of Economic Psychology, 12(3): 465-478.

6. Cantner, U., Silbereisen, R. K., \& Wilfling, S. (2011). Which Big Five personality traits drive entrepreneurial failure in highly innovative industries? DIME Final Conference, (pp. 1-51). Maastricht.

7. Chell, E. (2000) 'Towards Researching the "Opportunistic Entrepreneur": A Social Constructionist Approach \& Research Agenda', European Journal of Work and Organisational Psychology 9(1): 63-80.

8. Ciavarella, M. A., Buchholtz, A. K., Riordan, C., Gatewood, R. D., \& Stokes, G. S. (2004). The big five and venture survival; is there a linkage? Journal of Business Venturing , 465-483.

9. Fasanmi S. S (2017). Computer Statistical analysis in Social Sciences in O. O. Adetola, R. Aborishade, and S. Fasanmi (eds), Research Methods in Social and Sciences. (pp 68-106). Ibadan University Press. ISBN: 978-978-8529-35-4.

10. Fasanmi S.S. (2018). Effects of Commitment, Justice and Empowerment on Organisational Citizenship Behaviour and Turnover Intent among Nigerian Bankers, Ife PsychologIA 26 (1), (Published by The Ife Centre for Psychological Studies, Ile-Ife, Nigeria. https://www.ajol.info/index.php/ifep/article/view/169511

11. Festinger, L. (1957). A theory of cognitive dissonance, Evanston, IL: Row \& Peterson.

12. Goldberg, L. R. (1990). An Alternative "Description of Personality": The Big-Five Factor Structure. Journal of Personality and Social Psychology, 1216-1229.

13. Hampton, K. N. and Wellman, B. (1999). Netville On -Line and OffLine, American Behavioral Scientist, 43(3), p. 478-495. 
14. Haythornthwaite, C. and Wellman, B. 1998. Work, Friendship and Media Use For Information Exchange in a Networked Organization, Journal of the American Society for Information Science. 49 (12), p. 1101-1114.

15. Hogan, J., \& Ones, D. S. (1997). Conscientiousness and integrity at work. In R. Hogan, J. Johnson, \& S. Briggs, Handbook of personality psychology (pp. 849-870). San Diego: Academic Press.

16. Hurtz, G. M., \& Donovan, J. (2001). Personality and Job Performance, The Big Five Revisited. Journal of Applied Psychology, 869-879.

17. Ismail, M; Khalid, S.A; Othman, M; Jusoff, K; Abdul Rahman, N; Mohammed, K.M \& Shekh, R.Z. (2009). Entrepreneurial intention among Malaysian undergraduates. International Journal of Business and Management, 4 ,(10), 54-60.

18. John, O. P., \& Srivastava, S. (1999). The Big-Five trait taxonomy: History, measurement, and theoretical perspectives. In L. A. Pervin \& O. P. John (Eds.), Handbook of personality: Theory and research (Vol. 2, pp. 102-138). New York: Guilford Press.

19. Kaczmarek, M., \& Kaczmarek -Kurczak, P. (2016). Personality traits and self-efficacy as predictors of business performance: A longitudinal study. Annals of Psychology, 121-137.

20. Kolvereid, L. \& Isaksen, E. (2006). New business start-up and subsequent entry into self-employment. Journal of Business Venturing, 21(6), 866-885.

21. Krueger, N.F. Jr, Reilly, M.D. and Carsrud, A.L. (2000), "Competing models of entrepreneurial intentions", Journal of Business Venturing, 15, pp. 411-32.

22. Laguna, M., Moriano, J.A., Roznowki, B., \& Góm ez, A. (2008). Entrepreneurship in Polish and Spanish students explained by means of the theory of planned behavior. Studia Psychologiczne (Psychological Studies), 46, 27-40.

23. Lenhart, A., Rainie, L., \& Lewis, O. (2001, June 20). Teenage life online: The rise of the instant-message generation and the internet's impact on friendships and family relationships. Washington, DC: Pew Internet and American Life Project.

24. Leutner, F., Ahmetoglu, G., Akhtar, R., \& Chamorro-Premuzic, T. (2014). The relationship between the entrepreneurial personality and the Big Five personality traits. Personality and individual differences, 58-63.

25. McClelland, D. C. and D. G. Winter (1971). Motivating Economic Achievement. New York: Free Press. 
26. McCrea, R. R., \& Costa, P. T. (1997). Personality trait structure as a human universal. American Psychologist, 509-516.

27. Moriano, J. A. (2005). El perfil psicosocial del emprendedor [The psychosocial profile of the entrepreneur]. Madrid: Consejo Económico y Social.

28. Premium Times, June 12, 2017. "Nigeria's active telecoms subscribers reduced to 149 million in April - NCC" https://www.premiumtimesng.com/business/business-data/233815nigerias-active-telecoms-subscribers-reduced-to-149-million-in-aprilncc.html

29. Rauch, A. and M. Frese (2000). 'Psychological approaches toentrepreneurial success: A general model and an overview of findings'. International Review of Industrial and Organizational Psychology15,101-142.

30. Rauch, A. and M. Frese (2007), 'Let's put the person back into entrepreneurship research: A meta-analysis on the relationship between business owners' personality traits, business creation and success'. European Journal of Work and Organizational Psychology 16, 353-385.

31. Rice, R. E. (1993). Using network concepts to clarify sources and mechanisms of social influence. In W. D. Richards, Jr., \& G. A. Barnett (Eds.), Progress in communication sciences, Vol. 12: Advances in communication network analysis (pp. 43-62). Norwood, NJ: Ablex.

32. Roccas, S., Sagiv, L., Schwartz, S. H., \& Knafo, A. (2002). The Big Five personality factors and personal values. Personality and Social Psychology Bulletin, 28(6), 789-801. http://dx.doi.org/10.1177/014616720228900

33. Rotter, J. B. (1972), 'Generalized expectancies for internal versus exter-nal control of reinforcement'. In: J. B. Rotter, J. E. Chance, and E. J.Phares (eds.): Applications of a Social Learning Theory of Personality. New York: Holt, pp. 260-294.

34. Sackett, P. R., \& Wanek, J. E. (1996). New developments in the use of measures of honesty, integrity, conscientiousness, dependability, trustworthiness and reliability for personnel selection. Personnel psychology, 787-829.

35. Saucier, G., \& Goldberg, L. R. (1998). What is beyond the big five? Journal of Personality, 495-524.

36. Saucier, G., \& Ostendorf, F. (1999). Hierarchical subcomponents of the Big Five personality factor s: A cross-language replication. Journal of Personality and Social Psychology, 613-627. 
37. Slavec, A. (2014). Determinants of SME Performance: the impact of entrepreneurial openness and goals. 7th international scientific conference (pp. 645-652). New York: Economic and Social Development .

38. Tellegen, A. (1993). Folk concepts an d psychological concepts of personality and personality disorder. Psychological Inquiry, 122-130.

39. Thornton, W. B. (1999). The Sociology of Entrepreneurship. Annual Review of Sociology. Annual Review of Sociology 25(1):19-46.

40. Utsch, A., A. Rauch, R. Rothfuss, and M. Frese (1999), 'Who becomes a small scale entrepreneur in a post-socialist environment: On thedifferences between entrepreneurs and managers in East Germany'.Journal of Small Business Management 37 (3), 31-42.

41. van Gelderen, M., Brand, M., van Praag, M., Bodewes, W., Poutsma, E., \& van Gils, A. (2008). Explaining entrepreneurial intentions by means of the theory of planned behaviour. Career Development International, 13, 538-559. doi: 10.1108/13620430810901688

42. Wellman, B., Quan-Haase, A., Witte, J., \& Hampton, K. (2001). Does the Internet increase, decrease, or supplement social capital? Social networks, participation, and community commitment. American Behavioral Scientist, 45 (3), 437-456.

43. Winnie, J.F., and Gittinger, J.W. (1973). An introduction to the personality assessment system. Journal of Clinical Psychology, Monograph Supplement, 38: 1-68.

44. Zahra, S.A. 1991. Predictors and financial outcomes of corporate entrepreneurship: An exploratory study. Journal of Business Venturing, 6(4), 259-285.

45. Zhao, H., Seibert, S. E., \& Lumpkin, G. T. (2010). The relationship of personality to entrepreneurial intentions and performance: A metaanalytic review. Journal of Management, 36, 381-404. 